\title{
Perlindungan Hukum bagi Buruh Migran Terhadap Tindakan Perdagangan Perempuan
}

\author{
Devi Rahayu \\ Fakultas Hukum Universitas Trunojoyo Madura \\ Jl.Raya Telang PO BOX 2 Kamal Bangkalan \\ rechtidee@yahoo.com
}

\begin{abstract}
The problem which was appointed in this research; first, is there any trafficking of women in cases happened in the process of migrant workers delivery in Kabupaten Bangkalan and Sampang? Second, can the valid regulations be used to conduct the protection for migrant workers in the process of migrant workers delivery from the trafficking of women as well as the appropriate legal protection in order to prevent the trafficking of women practice? The method used in this research was juridical empiric, while the data collecting method was; observation, structured interview, and deep interview. The data analyzing method was performed by content analysis, with the use of formal interpretation method, analogy, and extensive. The result showed that in the process of the migrant workers delivery, there were elements of human trafficking, such as; over-limited actions, violence or threats of violence, fraud, debt bondage, violence with abuse of power, and forced labor or the condition similar with slavery. The regulation of migrant workers delivery has not entirely arranged the related protection on trafficking action.
\end{abstract}

Key words : Legal protection, migrant workers, trafficking of women

\begin{abstract}
Abstrak
Permasahan yang diangkat dalam penelitian ini, Pertama, apakah dalam kasus-kasus yang terjadi pada proses pengiriman buruh migran di Kabupaten Bangkalan dan Sampang terdapat unsur-unsur perdaganagn perempuan (trafficking) ? Kedua, apakah peraturan yang berlaku telah dapat digunakan untuk melaksanakan perlindungan bagi buruh migran dalam proses pengiriman buruh migran dari tindakan perdagangan perempuan serta perlindungan hukum yang bagaimana yang sesuai guna menghindarkan terjadinya tindakan perdagangan perempuan? Metode pendekatan penelitian yang digunakan dalam penelitian ini adalah yuridis empiris, sedangkan metode pengumpulan data dilakukan dengan cara : observasi, wawancara terstruktur, dan wawancara mendalam. Metode analisis data dilakukan secara content analysis, dengan menggunakan metode interpretasi formal, analogi dan ekstensif. Hasil penelitian menunjukkan bahwa dalam proses pengiriman buruh migran terdapat unsur perdagangan manusia, seperti : adanya tindakan melintasi batas, adanya tindakan kekerasan atau ancaman kekerasan, adanya penipuan, lilitan hutang, kekerasan dengan penyalahgunaan kekuasaan dan kerja paksa atau kondisi seperti perbudakan. Peraturan pengiriman buruh migran belum mengatur secara keseluruhan terkait perlindungan dari tindakan trafficking.
\end{abstract}

Kata kunci : Perlindungan hukum, buruh migran, perdagangan perempuan 


\section{Pendahuluan}

Masalah tenaga kerja Indonesia (TKI) yang bekerja ke luar negeri mulai mengemuka lagi ketika pembangunan di pedesaan Indonesia dengan revolusi hijaunya mempunyai implikasi yang menyebabkan banyak tenaga kerja terutama perempuan, terdorong ke luar (push-factor) dari pedesaan, terutama di pedesaan di Jawa. Di sisi lain, perkembangan relokasi industri di negara-negara tempat TKI bekerja merupakan penariknya (pull-factor) ${ }^{1}$

Pemerintah lewat Kementrian Tenaga Kerja memahami bahwa pengiriman buruh migran keluar negeri adalah aset bagi penambahan devisa negara, yaitu lewat remintance yang berasal dari pengiriman upah buruh migran ke Indonesia. Sehingga tak dapat disalahkan jika Departemen Tenaga Kerja menargetkan antara tahun 19992004 akan mengirim sebanyak 2.800.000 pekerja formal dan informal, dengan target penerimaan devisa total sebesar US\$13.000.000.000 (Rp. 12.500.000.000.000,00). Jika target ini terpenuhi, maka buruh migran menyumbang 1,8\% untuk Anggaran Pengeluaran Belanja Negara (APBN) 1999-2000 sebesar Rp. 219.400.000.000.000,00.² Namun hal tersebut jika di lihat secara rasional penghasilan buruh migran dinilai sangatlah kecil jika dibandingkan dengan jumlah yang harus dikeluarkan oleh bangsa kita untuk membayar tenaga asing yang bekerja di Indonesia. ${ }^{3}$

Dengan adanya Undang-Undang No. 39 Tahun 2004 tentang Penempatan dan Perlindungan Tenaga Kerja Indonesia di Luar Negeri, diharapkan mampu memberikan upaya perlindungan yang integral serta system penempatan yang lebih mudah bagi TKI. Selain itu dalam Undang-Undang juga mengamanatkan untuk membentuk Badan Nasional Penempatan dan Perlindungan Tenaga kerja Indonesia (BNP2TKI) yang baru terbentuk pada April 2007 mempunyai tugas secara khusus menangani persoalan TKI dan mengupayakan perlidungan bagi TKI secara optimal. Keberadaan UU dan BNP2TKI diharapkan mampu memberikan kepastian hukum dan perlindungan hukum serta menjawab segala persoalan yang dihadapi oleh TKI.

Laporan dari The Internasional Organisation For Migran, yang mencatat sekitar 500.000 perempuan tiap tahun menjadi korban yang kesemuanya berasal dari

\footnotetext{
${ }^{1}$ Rachmat Syafa'at, Dagang Manusia : Kajian Trafficking terhadap Perempuan dan Anake di Jawa Timur, Lappera Pustaka Utama, Yogyakarta, hlm. 15.

${ }^{2}$ Kompas, 23 September 2000

${ }^{3}$ Solidaritas Perempuan, Ham Dalam Praktek, Panduan Melawan Perdagangan Perempuan Dan Anak, Jakarta, 2000, hlm. 143
} 
negara-negara miskin atau negara yang sedang berkembnag dengan latar belakang pendidikan yang rendah. ${ }^{4}$ Dari data yang penulis kumpulkan tentang trafficking in person, memperlihatkan adanya kecenderungan peningkatan kuantitas dan modus operandi yang semakin canggih. Badan Reserse dan Kriminal Kepolisian RI selama 2003-2007 mencatat 492 kasus perdagangan orang dengan melibatkan 1.015 orang dewasa dan 238 anak-anak. Sementara itu, Organisasi Internasional untuk Migrasi (IOM) dari 2005 hingga Januari 2008 mencatat 3.024 orang yang menjadi korban. ${ }^{5}$

Fenomena perdagangan orang di Indonesia sejak krisis yang lalu, kini dicurigai semakin meningkat. Tidak saja terbatas untuk tujuan prostitusi atau eksploitasi seksual orang, melainkan juga meliputi bentuk-bentuk eksploitasi lain, seperti kerja paksa dart praktik menyerupai perbudakan di beberapa wilayah sektor Informal, termasuk kerja domestik dan mempelai pesanan. Perdagangan orang merupakan tindakan kejahatan yang sangat merendahkan martabat orang dan merupakan bentuk perbudakan orang di jaman modem. Oleh karena itu perlu mendapat perhatian dan penanganan yang serius.

Karenanya banyak pihak beranggapan bahwa perdagangan perempuan adalah masalah dunia yang harus diputuskan secara bersama-sama atau diperlukannya keberadaan suatu aturan yang bersifat internasional. Namun tentunya hal tersebut harus harus juga diimbangi dengan aturan yang bersifat nasional yang diharapkan mampu memberika tindakan preventif bagi tindakan perdagangan perempuan.

Diundangkannya Undang-Undang No. 21 Tahun 2007 tentang Pemberantasan Tindak Pidana Perdagangan Orang, membawa harapan baru dan tantangan bagi para aparatur hukum dan pemerhati terjadinya tindak pidana perdagangan orang, untuk kembali memperhatikan dan mempelajari unsur-unsur dan sistem perlindungan hukum (terutama bagi saksi korban) dalam tindak pidana perdagangan orang. Sebagai undangundang yang baru, tentunya akan banyak permasalahan dalam penerapannya, terutama dengan adanya unsur-unsur dan sistem perlindungan hukum (kompensasi, restitusi, repatriasi dan rehabilitasi) bagi korban. Karena unsur-unsur dan ketentuan perlindungan hukum tersebut merupakan hal baru dalam sistem hukum pidana Indonesia. Tentunya hal ini merupakan tugas yang berat dan perlu pendalaman tersendiri untuk mempelajari dan menerapkannya. Oleh karena itu, segala permasalahan yang akan terjadi perlu diantisipasi dengan baik dan harus ada jalan keluar untuk mengatasi permasalahannya.

\footnotetext{
${ }^{4}$ Nina Stunberg, "What is trafficking in women and childrenwhat can be done", November, 1999, www.IOM.int, diakses pada 7 Juli 2010

${ }^{5}$ Muchsin, “Tindak Pidana Perdagangan Orang”, Varia Peradilan, No. 272 Juli 2008, hlm. 6
} 
Dari uraian tersebut diatas, maka diperlukan suatu kajian yang mendalam tentang tindakan perdagangan perempuan pada proses pengiriman buruh migran di Kabupaten Bangkalan dan Sampang, bagaimana perlindungan hokum yang telah dilakukan oleh Pemerintah serta perlindungan hokum yang sasuai guna pencegahan terjadinya trafficking.

\section{Rumusan Masalah}

Berdasarkan uraian singkat di atas maka permasalahan yang dapat dikemukakan adalah: Pertama, apakah dalam kasus-kasus yang terjadi pada proses pengiriman buruh migran di kabupaten Bangkalan dan Sampang terdapat unsurunsur perdaganagn perempuan (trafficking) ? Kedua, apakah peraturan yang berlaku telah dapat digunakan untuk melaksanakan perlindungan bagi buruh migran dalam proses pengiriman buruh migran dari tindakan perdaganagn perempuan serta perlindungan hukum yang bagaimana yang sesuai guna menghindarkan terjadinya tindakan perdagangan perempuan?

\section{Tujuan Penelitian}

Pertama, untuk menjelaskan apakah dalam kasus-kasus yang terjadi pada proses pengiriman buruh migran di kabupaten Bangkalan dan Sampang terdapat unsurunsur perdaganagn perempuan (trafficking). Kedua, untuk menjelaskan apakah peraturan yang berlaku telah dapat digunakan untuk melaksanakan perlindungan bagi buruh migran dalam proses pengiriman buruh migran dari tindakan perdaganagn perempuan serta menjelaskan perlindungan hukum yang bagaimana yang sesuai guna menghindarkan terjadinya tindakan perdagangan perempupuan.

\section{Metode Penelitian}

Metode pendekatan yang dipergunakan dalam penelitian ini adalah yuridis empiris, yaitu penelitian yang didasarkan pada perundang undangan dan juga menggunakan penelitian yang didasarkan pada fakta, realita dan permasalahan yang ada di lapangan. ${ }^{6}$ Secara yuridis peneliti akan mencermati peraturan-peraturan yang

\footnotetext{
${ }^{6}$ Soerjono Soekanto, Pengantar Penelitian Hukum, Universitas Indonesia, Jakarta, 1986, hlm 46
} 
berlaku saat ini, apakah telah dapat digunakan untuk melindungi buruh migran perempuan dari tindak perdangangan perempuan dengan meode pegumpulan data dengan studi pustaka. Sedangkan secara empiris peneliti akan melakukan penelaahan terhadap proses pengiriman buruh migran di Kabupaten Bangkalan dan Sampang yang dilakukan dengan metode pengumpulan data secara wawancara terstruktur, wawancara mendalam (indepth interview) dan observasi lapangan. Yang selanjutnya akan dipilah terhadap kasus-kasus yang dialami buruh migran yang termasuk kasus Trafficking.

Penelaahan secara yuridis empiris dilakukan dengan cara deskriptif, yang menggambarkan secara jelas mengenai proses pengiriman buruh migran di Kabupaten Bangkalan dan Sampang dalam keterkaitannya dengan tindakan perdagangan perempuan serta perlindungan hukum yang selama ini telah dilakukan oleh pemerintah terhadap buruh migran perempuan.

Penelitian ini merupakan penelitian yuridis empiris, karenanya sumber data yang akan digunakan dalam penelitian ini adalah : data primer merupakan datadata yang didapatkan dari studi dan penelaahan yang dilakukan dilapangan. Untuk penelitian ini, maka data primernya di dapatkan dari penggalian proses pengiriman buruh migran ke luar negeri yang dilakukan Pemerintah Daerah Kabupaten Bangkalan dan Sampang. Data sekunder merupakan data-data yang diperoleh dari bahan-bahan pustaka.

Setelah dilakukan pengolahan data, maka selanjutnya analisa data yang dilakukan adalah secara content analysis, dengan menggunakan metode interpretasi formal, analogi dan ekstensif terhadap : a) kasus-kasus tindakan perdagangan perempuan pada kasus-kasus yang terjadi dalam proses pengiriman buruh migran di kabupaten Bangkalan dan Sampang, b) peraturan-peraturan yang berlaku, telah memberikan perlindungan bagi buruh migran perempuan dari tindakan perdagangan perempuan atau tidak

\section{Hasil dan Pembahasan}

\section{Perdagangan Perempuan dan Hak Asasi Manusia}

Awal timbulnya tindakan perdagangan manusia sendiri berawal pada saat terjadinya peperangan Perang Dunia II. Namun saat itu hanya menjadi semacam 
isu semata tanpa adanya tindakan dari masyarakat internasional untuk meresponnya. Hingga kemudian isu perdagangan manusia makin marak dibicarakan setelah adanya institusi baru yang berdiri pada 1994 yaitu World Trade Organization (WTO), ${ }^{7}$ memberi batasan terbuka yang dapat diinterpretasikan bahwa pengiriman tenaga kerja bisa masuk pada bidang jasa Gander Automated Air Traffic System (GAATS) yang pada intinya ingin menciptakan suau tatanan masyarakat secara internasional yang berbasis pada globalisasi di bidang ekonomi.

Mulailah saat itu terjadi lintas batas secara bebas atas barang dan jasa, yang keseluruhannya tentu saja bertujuan untuk peningkatan keuntungan ekonomi suatu negara. Dan lintas batas tenaga kerja pun juga terjadi dan tak bisa dihindari, namun selanjutnya yang menjadi permasalahan adalah ternyata adanya pihak-pihak yang memanfaatkan arus migrasi ini untuk kepentingannya sendiri. ${ }^{8}$

Arus migrasi inipun jika kita amati polanya, maka akan dapat kita lihat bahwa perpindahan tenaga kerja itu terjadi dari negara yang berkembang menuju ke negara maju atau dari negara yang tergolong miskin ke negara yang lebih makmur. Pengiriman tenaga kerja ke negara lain ini ternyata justru merupakan suatu tindakan yang pada akhirnya cenderung menimbulkan tindakan yang bersifat melanggar martabat manusia. Ini dapat kita lihat data dari US Administration Conggres, bahwa korban perdagangan manusia terbesar adalah Asia dengan 255.000 korban tiap tahunnya. ${ }^{9}$ Dimana korban utamanya adalah kaum perempuan dan anak perempuan.

Kecenderungan yang semacam itu, dimana perempuan selalu dijadikan obyek dari suatu kegiatan yang notabene memberikan keuntungan pada segelintir orang, membuat beberapa pihak internasional memberikan suatu peraturan yang secara tegas melarang terjadinya tindakan perdagangan perempuan. Karenanya dalam beberapa konferensi internasional dibahas tentang tindakan perdagangan perempuan serta memasukkan tindakan tersebut sebagai salah satu bentuk tindak kejahatan.

Adapun konvensi internasional yang mengatur ataupun berkaitan dengan perdagangan perempuan adalah : $\left.{ }^{10} 1\right)$ 1948, Universal Declaration of Human Rights antara Pasal 3 sampai 21 berupa hak bebas dari perbudakan dan penghambatan dan hak bebas

\footnotetext{
${ }^{7}$ Bonny Setiawa, Stop WTO, INFID, Jakarta, 2000, hlm. 7

${ }^{8}$ Boer Mauna, Hukum Internasional Pengertian Peranana Fungsi dalam Era Dinamika Global, Alumni, Bandung, 2000, hlm. 7.

${ }^{9}$ Francis T. Miko, "Trafficking in women and children". The US and International Respons, Congressional Research Service Report, 2000, hlm. 4

${ }^{10}$ Rahayu, "Penguatan Hak-hak Buruh Migranmelalui Pelibatan CBO sebagai Upaya Pencegahan Perdagangan Perempuan di Madura”, Jurnal MKP Tahun XXII No.2 April-Juni 2009, hlm. 142
} 
dari penyiksaan atau perlakuan yang tak berprikemanusiaan ataupun yang merendahkan derajat kemanusiaan, 2) 1976, Convenant on Economic, Sosial and Cultural, berupa hak atas perlindungan sosial, standart hidup yang pantas, standart kesejahteraan fisik dan mental tertinggi yang bisa dicapai, 3) 1976, Convenant of Civil and Political Rights Pasal 8 ayat (1), hak-hak kebebasan dalam bergerak serta pelarangan terhadap tindakan perbudakan dan kerja paksa, 4) 1979 Art : 6, UN CEDAW, diratifikasi Indonesia dalam Undang-Undang No. 7 Tahun 1984 tentang Penghapusan Segala Bentuk diskriminasi Terhadap Perempuan dalam pasal 6 yang berbunyi : Negara-negara peserta wajib membuat peraturan-peraturan yang tepat, termasuk pembuatan undang-undang, untuk memberantas segala bentuk perdagangan wanita dan eksploitasi pelacuran, 5) 1992 General Recommedation 19 CEDAW, berupa deklarasi penghapusan kekerasan terhadap perempuan, 6) 1995 Beijing Platform of Action, yang berasal dari laporan berbagai negara di dunia tentang pelanggaran Hak Asasi Manusia (HAM) yang terjadi pada perempuan, sehingga merekomendasikan untuk mensosialisasikan penghentian segala bentuk kekerasan terhadap perempuan, dimana salah satu agendanya adalah penghentian segala bentuk perdagangan perempuan, 7) 1999 UN Convention Transnational Organized Crime, Art 3 memberikan batasan tentang tindakan perdagangan perempuan.

Keseluruhan konvensi Internasional diatas adalah sebagai tanggapan dari dunia Internasional atas semakin banyaknya korban dari perdagangan perempuan. Banyak pihak berpendapat bahwa masalah perdagangan perempuan ini tidak hanya dapat dihadapi oleh instrumen hukum internasional saja, tapi juga tetap dibutuhkan instrumen hukum nasional sebagai pencegahan tindakan perdagangan perempuan.

Indonesia sendiri baru meratifikasi satu dari konvensi Internasional tersebut yaitu CEDAW dalam UU No. 7 Tahun 1984 tentang Penghapusan Segala Bentuk Diskriminasi Terhadap Perempuan. ${ }^{11}$

\section{Identifikasi Kasus Buruh Migran Berdasar Pemahaman Perdagangan Perempuan}

Pemahaman buruh migran dalam Konvensi PP No 86 Tahun 1990 tentang Perlindungan terhadap pekerja migran dan keluarganya adalah : a migran worker is a person who is to be engangedor ha been enganged in a remuneratedin a state on which he or she is not national ${ }^{12}$.

\footnotetext{
${ }^{11}$ Rachmat Syafa'at, et. al., Burub Perempuan : Perlindungan Hukum dan hak. Asasi Manusia, IKIP Malang, 1998, hlm. 6.

${ }^{12}$ Sukamdi, et. al., Labour Migration in Indonesia, Population Studies Center, Gadjah Mada University, Yogyakarta, 2000, hlm. 3.
} 
Berdasarkan definisi perdagangan perempuan yang diberikan oleh GAATW yang berasal dari Transnational Organized Crime, Art 3 adalah semua usaha atau tindakan yang berkaitan dengan perekrutan, transportasi di dalam atau melintasi perbatasan, pembelian, penjualan, transfer, pengiriman atau penerimaan seseorang dengan menggunakan penipuan atau tekanan, termasuk penggunaan atau ancaman penggunaan kekerasan atau penyalahgunaan kekuasaan atau lilitan hutang dengan tujuan untuk menempatkan atau menahan orang tersebut, baik dibayar ataupun tidak, untuk kerja yang tidak diinginkannya (domestik, seksual atau reproduktif) dalam kerja paksa atau ikatan kerja atau dalam kondisi seperti perbudakan, dalam suatu lingkunagan lain dari tempat di mana orang itu tinggal pada waktu penipuan, tekanan atau lilitan hutang pertama kali. Merujuk pada UN protocol to Prevent, Suppress and Punish Trafficking in Persons, Especially Women and children, ${ }^{13}$ trafficking setidaknya terdiri atas tiga komponen, yaitu :1) rekrutmen (recruitment), 2) tranportasi (transportation), 3) perbatasan (border).

Dari definisi di atas, maka dapat kita lakukan identifikasi atas suatu tindakan yang merupakan definisi dari perdagangan perempuan berdasarkan kasus-kasus yang timbul pada TKI, yaitu :

\section{Segala usaha atau tindakan}

Dalam keseluruhan proses mulai dari pra pemberangkatan sampai dengan purna pemberangkatan, maka kasus yang selama ini menimpa para buruh migran adalah: 1) Pra pemberangkatan ${ }^{14}$ yang terdiri atas a) Pemberian informasi yang bersifat tidak jujur, yaitu hanya memberikan informasi tentang para buruh migran yang telah berhasil saja, b) Banyaknya terjadi kasus pemalsuan identitas, ini dilakukan oleh pihak sponsor berkaitan dengan usia dan pendidikan terakhir TKI, c) Pemberian pinjaman uang oleh para pihak sponsor dengan pengenaan bunga yang cukup tinggi. 2) Selama di negara tujuan atau masa kerja. Berbagai macam permasalahan dialami oleh buruh migran Indonesia selam bekerja di negara tujuan, untuk lebih mudah.

\section{Terkait dengan perekrutan dan transportasi}

Perekrutan adalah suatu usaha untuk merekrut atau mengajak seseorang untuk bergabung untuk melakukan suatu tindakan atau program tertentu. Perekrutan disini

${ }^{13}$ Mustain, "Perspektif Fenomenologi tentang Trafficking TKW", Jurnal MKP Unair, Tahun XXI No.2 AprilJuni 2008, hlm. 147. 
berkaitan dengan tindakan untuk mengajak seseorang untuk melakukan tindakan yang telah diprogramkan dengan melalui jalan bermigrasi. ${ }^{15}$ Tindakan perekrutan di sini adalah Perusahaan Jasa Tenaga Kerja Indonesia (PJTKI) untuk melakukan perekrutan terhadap para calon buruh migran, yang mana tindakan perekrutan ini biasanya dilakukan oleh para sponsor yang berada di daerah-daerah kantong buruh migran.

Transportasi adalah suatu alat yang dipergunakan untuk memindahkan suatu barang atau pun orang untuk menuju suatu tempat tertentu atau dapat dikatakan suatu alat pemindahan barang atau seseorang dari suatu tempat menuj suatu tempat tertentu.Transportasi yang digunakan untuk memindahkan buruh migran Indonesia untuk dapat melintasi batas negara kita menuju negara lain dapat berupa transportasi melalui darat, laut dan udara yang kesemuanya adalah upaya dari pihak perekrut/ PJTKI.

\section{Di dalam atau melintasi perbatasan}

Di sini masih terjadi banyak perdebatan, ada pihak yang berpendapat bahwa syarat terjadinya tindakan perdagangan perempuan adalah adanya tindakan lintas batas antara suatu negara dengan negara lain, atau melibatkan dua atau lebih negara. Pendapat yang kedua dirasa lebih fleksibel, dimana tindakan perdagangan perempuan tidak memerlukan lintas batas suatu negara, namun cukup adanya tindakan perpindahan seseorang dari daerah asalnya menuju daerah lain. Jadinya tindakan perdagangan perempuan dapat terjadi di suatu negara yang proses perpindahan seseorang tersebut berada pada negara yang sama.

Karenanya dalam mendefinisikan perdagangan perempuan sangat diperlukan keleluasaan tanpa terlalu kaku atau tepat dalam mendefinisikan perbatasan. Ini sangat diperlukan menyadari bahwa perempuan yang diperdagangkan adalah korban yang sudah dipindahkan ke lingkungan asing, dipisahkan dari jaringan pendukung fisik, emosional atau dengan bahasa atau budaya yang dikenalnya.

\section{Pembelian, penjualan, transfer, pengiriman atau penerimaan seseorang}

Tindakan pembelian dan penjualan adalah tindakan perdagangan perempuan yang digunakan untuk kegiatan prostitusi atau istri pesanan. Pengiriman adalah tindakan mengirimkan seseorang dari suatu negara menuju negara lain. Sedang

\footnotetext{
${ }^{15}$ Darwin Prins, Hukum Ketenagakerjaan Indonesia, Citra Aditya Bhakti, Jakarta, 2000, hlm. 27.
} 
tindakan penerimaan adalah tindakan menerima seseorang yang dikirim dari negara lain. Jadi disini menyangkut dua negara yaitu negara pengirim dan negara penerima.

Pada proses pengiriman buruh migran Indonesia yang terjadi adalah kegiatan yang dilakukan oleh pihak PJTKI untuk mengirim buruh migran kita ke luar negeri. Dalam kegiatan pengirian buruh migran ini, selain PJTKI juga terkait pihak Depnaker, BP2TKI dan imigrasi (dalam pengurusan paspor). Sedangkan kegiatan penerimaan adalah tindakan penerimaan buruh migran Indonesia di negara tujuan. Penerimaan buruh migran ini dilakukan oleh pihak wakil dari PJTKI yang ditempatkan di negara yang bersangkutan atau tenaga kerja yang telah ditunjuk oleh pihak PJTKI di Indonesia. Selain itu pihak yang terkait dalam proses penerimaan disini adalah pihak Perwakilan RI yang bertugas mendaftar kedatangan warga negara RI.

Dengan penipuan, penggunaan atau ancaman kekerasan, penyalahgunaan kekuasaan dan lilitan hutang

Tindakan penipuan disini dapat berupa janji palsu atau ingkar janji yang berupa ketidaksesuaian dengan kontrak perjanjian yang telah disepakati. Jadi penipuan yang dimaksud disini dapat berupa hal-hal yang berhubungan dengan kondisi kerja atau jenis pekerjaan yang harus dilakukan.

Penggunaan atau ancaman kekerasan, dimana kekerasan yang didasarkan pada Deklarasi PBB tentang Penghapusan Kekerasan terhadap Perempuan adalah : ${ }^{16} 1$ ) Kekerasan fisik, 2) Kekerasan psikologis, 3) Kekerasan seksual, 4) Kekerasan ekonomi, 5) Perampasan kemerdekaan secara sewenang-wenang

\section{Dengan tujuan untuk menempatkan atau menahan orang tersebut, dengan dibayar atau tidak dibayar}

Tujuan penempatan disini adalah menempatkan para buruh migran ke tempattempat yang telah dijanjikan untuk dipekerjakan pada seorang/ badan hukum yang merupakan pihak majikan. Begitu sampai di negara tujuan dan setelah ditempatkan di tempat kerjanya yang secara umum terjadi adalah penahanan dokumen yang dilakukan oleh majikan, ini dilakukan agar buruh migran tidak lari. Karenanya banyak buruh migran yang walupun mendapat tindakan kekerasan tetap berada di tempat majikannya, karena dokumennya ditahan. Serta ketidakpahaman buruh

${ }^{16}$ LBH Apik dan Pusat Studi Gender FH Unibraw, Naskah Akademik Peraturan Perundang-undangan tentang KDRT, Malang, 2000, hlm. 56 
migran atas isi kontrak kerja, sehingga mereka sering melakukan pekerjaan melebihi kewajiban dalam kontrak. ${ }^{17}$

\section{Untuk kerja yang tidak diinginkan (domestik, seksual dan reproduksi)}

Kerja yang tidak diinginkan disini adalah pekerjaan yang serupa pekerjaan domestik, seksual dan reproduksi. Untuk pekerjaan domestik dikategorikan didalamnya karena pekerjaan domestik juga merupakan pekerjaan yang tidak memerlukan pendidikan secara formil dan umumnya dilakukan oleh seseorang yang memiliki pendidikan yang rendah. Pekerjaan domestik merupakan pekerjaan yang meletakkan perempuan pada kedudukan yang subordinatif. ${ }^{18}$

\section{Dalam suatu kerja paksa atau ikatan karja yang kondisinya seperti perbudakan}

Pada zaman seperti sekarang ini, praktik-praktik tentang perbudakan yang berdasarkan zaman jahiliyah dulu sebenarnya sudah tidak ada lagi, karena konsepsi perbudakan saat itu adalah manusia dapat diperdagangkan dan dapat dimiliki oleh seseorang.

Namun jika dilihat secara lebih kritis terhadap fenomena buruh migran yang bekerja di sektor domestik. Secara formal beban kerja yang dibebankan pada seorang pekerja domestik sebenarnya telah ditetapkan di masing-masing negara yang telah meratifikasi ketentuan International Labour Organization (ILO). Namun pada kenyataannya banyak terjadi penyimpangan berupa beban kerja yang panjang dari ketentuan yang ada.

\section{Dalam suatu lingkungan lain dari tempat dimana orang itu tinggal pada waktu} terjadinya penipuan, tekanan atau lilitan hutang

Dalam suatu lingkungan lain artinya terjadinya keadaan kerja yang menyerupai perbudakan itu berbeda dengan tempat dimana korban mengalami kejadian penipuan atau lilitan hutang. Jadi disini terdapat dua tempat kejadian yang berbeda, yang pertama tempat dimana korban mengalami tindakan penipuan atau lilitan hutang, sedang tempat yang kedua adalah tempat dimana korban mengalami keadaan atau ikatan kerja yang menyerupa perbudakan.

Dalam kegiatan ini ada dua tempat kejadian, yaitu: 1) Negara pengirim/ negara asal: Ini adalah negara Indonesia dalam hal ini daerah Kabupaten bangkalan dan

\footnotetext{
${ }^{17}$ Abdul Haris, Gelombang Migrasi dan Jaringan Perdagangan Manusia, Pustaka Pelajar, Yogyakarta, 2005, hlm. 30.

${ }^{18}$ Mansour Fakih, Gender dan Transformasi Sosial, Jakarta, 1998, hlm. 27.
} 
Sampang, dimana tempat terjadinya tindakan penipuan, tekanan penipuan atau lilitan hutang, 2) Negara Penerima: Ini adalah negara tempat bekerjanya buruh migran dan pada tempat ini terjadi kondisi kerja seperti perbudakan.

Dari keseluruhan unsur-unsur tindakan perdagangan perempuan, maka dari data lapangan didapatkan kasus-kasus trafficking yang menimpa buruh migran yang berasal dari Bangkalan dan Sampang seperti disajikan pada Tabel 1.

Tabel 1

Kasus yang Terjadi Pada Buruh Migran di Kabupaten Bangkalan dan Sampang Berkaitan Tindakan Trafficking

\begin{tabular}{|c|c|c|}
\hline KASUS & TRAFFICKING & Hak Asasi Manusia \\
\hline $\begin{array}{l}\text { a. Pemalsuan identita } \\
\text { b. Berangkat melalui calo } \\
\text { dengan biaya } 4 \text { juta } \\
\text { c. Penampungan berada di } \\
\text { Malaysia } \\
\text { d. Diajak berhubungan badan } \\
\text { saat di penampungan } \\
\text { e. Kondisi penampungan } \\
\text { tidak layak } \\
\text { f. Pekerjaan tidak sesuai } \\
\text { dengan yang dujanjikan } \\
\text { g. Paspor dibawa majikan } \\
\text { h. Waktu kerja } 24 \text { jam } \\
\text { i. Kekerasan oleh majikan } \\
\text { berupa: penggunaan kata- } \\
\text { kata kasar dan tindakan } \\
\text { asusila } \\
\text { j. Pemotongan gaji oleh PT } \\
\text { selama } 7 \text { bulan }\end{array}$ & $\begin{array}{l}\text { 1. Tindakan lintas batas } \\
\text { 2. Adanya penipuan identitas dan } \\
\text { pekerjaan yang tidak sesuai } \\
\text { dengan yang dijanjikan } \\
\text { 3. Adanya tindakan kekerasan di } \\
\text { penampungan dan yang } \\
\text { dilakukan oleh majikan } \\
\text { 4. Adanya lilitan hutang } \\
\text { 5. Kekerasan yang dilakukan oleh } \\
\text { majikan karena adanya posisi } \\
\text { dominan berupa dokumen yang } \\
\text { dibawa majikan } \\
\text { 6. Kondisi seperti perbudakan }\end{array}$ & $\begin{array}{l}\text { Hak atas kebebasan dan } \\
\text { keamanan pribadi termasuk } \\
\text { perlindungan terhadap } \\
\text { kekerasan, penghinaan } \\
\text { (pelecehan) anggota tubuh, } \\
\text { ancaman dan intimidasi. }\end{array}$ \\
\hline $\begin{array}{l}\text { a. Berangkat dengan paspor } \\
\text { wisata } \\
\text { b. Biaya berangkat sebesar } 6 \\
\text { juta } \\
\text { c. Penampungan berada di } \\
\text { Malaysia dan berada di } \\
\text { tengan hutan } \\
\text { d. Diajak berhubungan badan } \\
\text { di penampungan agar } \\
\text { cepat ditempatkan } \\
\text { e. Tidak ada kontrak kerja } \\
\text { f. Pekerjaan tidak sesuai } \\
\text { dengan yang dijanjikan } \\
\text { g. Waktu kerja } 24 \text { jam } \\
\text { h. Kekerasan oleh majikan } \\
\text { berupa : tindakan asusila }\end{array}$ & $\begin{array}{l}\text { 1.Tindakan lintas batas } \\
\text { 2. Adanya tindak kekerasan yang } \\
\text { terjadi di penampungan dan yang } \\
\text { dilakukan majikan } \\
\text { 3. Kekerasan dengan } \\
\text { penyalahgunaan kekuasaan atau } \\
\text { posisi dominan (terjadi di tempat } \\
\text { kerja/negara penerima), berupa } \\
\text { paspor wisata dan tidak ada } \\
\text { kontrak kerja } \\
\text { 4. Kerja paksa atau kondisi seperti } \\
\text { perbudakan }\end{array}$ & $\begin{array}{l}\text { Hak atas kebebasan dan } \\
\text { keamanan pribadi termasuk } \\
\text { perlindungan terhadap } \\
\text { kekerasan, penghinaan } \\
\text { (pelecehan) anggota tubuh, } \\
\text { ancaman dan intimidasi. }\end{array}$ \\
\hline $\begin{array}{l}\text { a. Pemalsuan identitas } \\
\text { b. Berangkat melalui calo } \\
\text { dengan biaya } 15 \text { juta } \\
\text { c. Kondisi penampungan } \\
\text { yang tidak layak }\end{array}$ & $\begin{array}{l}\text { 1. Tindakan lintas batas } \\
\text { 2. Tindakan kekerasan yang terjadi } \\
\text { dipenampungan dan yang } \\
\text { dilakukan majikan } \\
\text { 3. Adanya tindak penipuan }\end{array}$ & $\begin{array}{l}\text { Hak atas kebebasan dan } \\
\text { keamanan pribaditermasuk } \\
\text { perlindungan terhadap } \\
\text { kekerasan, penghinaan } \\
\text { (pelecehan) anggota tubuh, }\end{array}$ \\
\hline
\end{tabular}




\begin{tabular}{|l|l|l|}
\hline $\begin{array}{l}\text { d.Diajak berhubungan badan } \\
\text { di lokasi penampungan } \\
\text { agar cepat ditempatkan }\end{array}$ & 4. Adanya lilitan hutang & ancaman dan intimidasi. \\
e. Waktu kerja 24 jam & & \\
f. Kekerasan oleh majikan : & & \\
menggunakan kata-kata & & \\
kasar dan dianiaya & & \\
g. Pemotongan gaji selama 5 & & \\
bulan & & \\
\hline
\end{tabular}

Sumber: Hasil analisa penulis ${ }^{19}$

Jadi dapat disimpulkan disini bahwa dalam proses pengiriman buruh migran Indonesia yang berasal dari kabupaten Bangkalan dan Sampang yang selama ini terdapat banyak kasus yang dialami oleh para buruh migran, ternyata pada kasuskasus yang timbul disini dapat diidentifikasikan sebagai tindakan perdagangan perempuan. Karena pada kasus-kasus yang timbul tersebut telah memenuhi unsurunsur dari tindakan perdagangan perempuan.

\section{Pengaturan Trafficking dan Ancaman Hukuman}

Bila dikaitkan dengan hak asasi manusia, trafficking ini termasuk salah satu bentuk pengingkaran hak asasi manusia. Sebagaimana dapat dilihat dalam UU tentang Hak Asasi Manusia, Pasal 3 yang berbunyi: Setiap orang dilahirkan bebas dengan harkat dan martabat manusia yang sama dan sederajat serta dikaruniai akal dan hati nurani untuk hidup bermasyarakat, berbangsa, dan bernegara dalam semangat persaudaraan. Setiap orang berhak atas pengakuan, jaminan, perlindungan dan perlakuan hukum yang adil serta mendapat kepastian hukum dan perlakuan yang sama di depan hukum. Setiap orang berhak atas perlindungan hak asasi manusia dan kebebasan dasar manusia, tanpa diskriminasi; Pasal 4 yang berbunyi: Hak untuk hidup, hak untuk tidak disiksa, hak kebebasan pribadi, pikiran dan hati nurani, hak beragama, hak untuk tidak diperbudak, hak untuk diakui sebagai pribadi dan persamaan di hadapan hukum, dan hak untuk tidak dituntut atas dasar hukum yang berlaku surut adalah hak asasi manusia yang tidak dapat dikurangi dalam keadaan apa pun dan oleh siapa pun; Pasal 20 yang berbunyi: Tidak seorang pun boleh diperbudak atau diperhamba. Perbudakan atau perhambaan, perdagangan budak, perdagangan wanita, dan segala perbuatan berupal apapun yang tujuannya serupa, dilarang; Pasal65 yang berbunyi: Setiap anak berhak untuk

\footnotetext{
${ }^{19}$ D. Rahayu, Trafficking Burub Migran, Qisthos Press, Surabaya, 2008, hlm. 52.
} 
memperoleh perlindungan dari kegiatan eksploitasi dan pelecehan seksual, penculikan, perdagangan anak, serta dari berbagai bentuk penyalahgunaan narkotika, psikotropika, dan zat adiktif lainnya.

Larangan mengenai perdagangan orang pada dasarnya telah diatur dalam beberapa undang-undang. Pasal 297 dan Pasal 324 Kitab Undang-Undang Hukum Pidana (KUHP) mengatur mengenai larangan perdagangan perempuan dan anak serta larangan memperdagangkan budak. Pasal 297 KUHP menentukan bahwa, "memperniagakan perempuan dan memperniagakan laki-laki yang belum dewasa, dipidana dengan pidana penjara paling lama 6 tahun". Pasal 324 menentukan bahwa, "barangsiapa dengan ongkos sendiri atau ongkos orang lain menjalankan perniagaan budak belian atau melakukan perbuatan perniagaan budak belian atau dengan sengaja turut campur dalam segala sesuatu itu, baik langsung maupun tidak langsung, dipidana dengan pidana penjara paling lama 12 tahun" ${ }^{20}$ Pasal 297 KUHP dan Pasal 324 KUHP tersebut, substansinya tidak memadai lagi dan belum dapat menjangkau tindak pidana yang sifatnya transnasional dan kejahatan yang terorganisasi.

Selain KUHP, ada beberapa undang-undang yang juga mengatur mengenai tindak pidana perdagangan orang, walaupun tidak secara khusus mengatur secara rinci mengenai perdagangan orang, misalnya Undang-Undang Nomor 23 Tahun 2002 tentang Perlindungan Anak yaitu Pasal 83 telah memberikan pemberatan pidana penjara paling lama 15 tahun dan paling singkat 3 tahun dan denda paling banyak Rp. 300.000.000,00 dan paling sedikit Rp. 60.000.000,00.

Besarnya dampak yang ditimbulkan dalam kejahatan perdagangan orang, tampaknya UU Tindak pidana pemberantasan perdagangan orang ini tidak mengenal ampun siapa pun yang terlibat. Para pelaku, mulai dari pejabat pemerintah sampai korporasi yang terbukti melakukan tindak pidana perdagangan orang akan terancam pidana penjara.

Undang-Undang Nomor 21 Tahun 2007 tentang Pemberantasan Tindak Pidana Perdagangan Orang Pasal 2 ayat (1) menentukan bahwa Setiap orang yang melakukan perekrutan, pengangkutan, penampungan, pengiriman, pemindahan, atau penerimaan seseorang dengan ancaman kekerasan, penggunaan kekerasan, penculikan, penyekapan, pemalsuan, penipuan, penyalahgunaan kekuasaan atau

${ }^{20}$ R.Soesilo, KUHP serta Komentar-komentarnya, Politea, Bandung, 1996, hlm. 211 
posisi rentan, penjeratan utang atau memberi bayaran atau manfaat walaupun memperoleh persetujuan dari orang yang memegang kendali atas orang lain, untuk tujuan mengeksploitasi orang tersebut di wilayah Negara Republik Indonesia, dipidana dengan pidana penjara paling singkat 3 tahun dan paling lama 15 tahun dan pidana denda paling sedikit Rp. 120.000.000,00 dan paling banyak Rp. $600.000 .000,00$. (2) Jika perbuatan sebagaimana dimaksud pada ayat (1) mengakibatkan orang tereksploitasi maka pelaku dipidana dengan pidana yang sama sebagaimana dimaksud pada ayat (1).

Pasal 2 di atas merupakan elemen tindak pidana perdagangan orang yang secara umum dianut di berbagai negara yang selama ini dikenal dengan sebagai elemen gerakan/pemindahan (movement), caranya (means), dan untuk tujuan eksploitasi. Pasal 2 tersebut terdapat dua macam delik yakni delik formil dan delik materiil. Ancaman pidana terhadap delik formil dan materiil tersebut sama besarnya, walaupun akibat yang ditimbulkan berbeda.

Selain menegakkan hukum, beban yang dipikul nantinya adalah melaksanakan tugas untuk melindungi saksi dan korban tindak pidana perdagangan orang. Ketentuan tersebut berbunyi: Pasal 44 (1) Saksi dan/atau korban tindak pidana perdagangan orang berhak memperoleh kerahasiaan identitas. (2) Hak sebagaimana dimaksud pada ayat (1) diberikan juga kepada keluarga saksi dan/atau korban sampai dengan derajat kedua, apabila keluarga saksi dan/atau korban mendapat ancaman baik fisik maupun psikis dan orang lain yang berkenaan dengan keterangan saksi dan/atau korban.

Melihat aturan serta undang-undang yang mengatur tentang trafficking ini telah cukup banyak, kalau misalnya bentuk kejahatan ini masih marak sebenarnya rujukan hukumnya telah tersedia. Yang terjadi adalah lemahnya penegakan hukum serta kinerja di jajaran yang belum mempunyai komitmen menegakkan keadilan terhadap kasus-kasus gender related violence. ${ }^{21}$

\section{Upaya Perlindungan Hukum yang Telah Dilakukan}

Perihal perlindungan hukum, maka hal tersebut merupakan bentuk konsekuensi dari bentuk negara hukum, dimana negara Indonesia berdasar atas hukum tidak berdasarkan atas kekuasaan semata. Dimana pemerintah berdasarkan

${ }^{21}$ Muchsin, Op. Cit., hlm. 14 
atas sistem konstitusi tidak bersifat absolutisme. ${ }^{22}$ Terkait perlindungan hukum sendiri dibedakan atas: ${ }^{23} 1$ ) perlindungan hukum preventif, yang bertujuanuntuk mencegah terjadinya permasalahan dan 2) perlindungan hukum represif, yang bertujuan untuk menyelesaikan permasalahan.

Upaya perlindungan secara hukun dalam bentuk undang-undang memang telah ada dalam UU No. 39 Tahun 2004 tentang Penempatan dan Perlindungan TKI di luar negeri. Dari konteks pemahaman tulisa sebenarnya dapat ditafsirkan bahwa keberadaan UU lebih banyak mengatur mengenai prasyarat dan tindakan teknis dari tindakan penempatan dari pada upaya perlindungannya.

Perihal tindakan penempatan TKI ke luar negeri merupakan posisi rentan terhadap tindak perdagangan orang sebenarnya sudah diantisipasi oleh Pemerintah. Ini dapat kita lihat pada Pasal 2 UU No 39 Tahun 2004 yang berbunyi: penempatan dan perlindungan calon TKI/TKI berasakan keterpaduan, persamaan hak, demokrasi, keadilan sosial, kesetaraan dan keadilan gender,anti diskriminasi serta anti perdagangan manusia.

Dalam konteks Undang-Undang tersebut pemerintah mempunyai kewajiaban untuk memberikan perlindungan pada buruh migran, yaitu diatur pada Pasal 77 1) Setiap calon TKI/TKI mempunyai hak untuk memperoleh perlindungan sesuai dengan peraturan perundang undangan, 2) Perlindungan sebagaimana yang dimaksud pada ayat (1) dilaksanakan mulai dari pra penempatan,, masa penempatan, sampai dengan proses penempatan.

Dalam penafsiran undang-undang tersebut dapat diakatakan bahwa hak dari buruh migran atas Pemerintah adalah mendapatkan perlindungan dalam keseluruhan proses penempatan buruh migran ke luar negeri. Namun secara realitas selama ini banyaknya kasus yang terjadi pada buruh migran adalah saat mereka berada di tempat kerja/di luar negeri. Permasalahannya selama ini adalah pihak kedutaan merasa bahwa karena tidak adanya atase tenaga kerja, maka persoalan buruh migran bukan persoalan Kedutaan. Belum lagi alasan ketiadaan dana. Karenanya dalam Pasal 78 ditegaskan bahwa : 1)Perwakilan Repiblik Indonesia memberikan perlindungan terhadap TKI di luar negeri sesuai dengan peraturan perundang-undangan serta hukum dan kebiasaan internasional, 2) Dalam rangka perlindungan TKI di luar negeri, Pemerintah dapat menetapkan jabatan atase ketenagakerjaan pada perwakilan

\footnotetext{
${ }^{22}$ Saukarto Marmo Sudjono, Penegakan Hukum di Negara Pancasila, Garuda Metropolis Press, jakarta, 1989, hlm. 16. ${ }^{23}$ Phillipus M. Hadjon, Perlindungan Hukum Bagi Rakyat di Indonesia, Surabaya, 1987, hlm. 2
} 
Republik Indonesia tertentu, 3) Penugasan atase ketenagakerjaan sebagaimana yang dimaksud pada ayat (2) dilakukan sesuai dengan peraturan perundang-undangan.

Mengenai bentuk-bentuk perlindungan yang diberikan oleh Pemerintah yang dalam hal ini dilakukan oleh pihak Kedutaan terhadap buruh migran, berupa Pasal 78 UU No. 39 Tahun 2004: 1) Perlindungan selama masa penempatan TKI di luar negeri dilaksanakan antara lain ; a) pemberian bantuan hukum sesuai dengan ketentuan perturan perundang-undangan di negara tujuan serta hukum dan kebiasaan internasional, b) pembelaan atas pemenuhan hak sesuai dengan perjanjian kerjadan/ atau peraturan perundang-undangan dinegara TKI ditempatkan, 2) Ketentuan mengenai pemberian perlindungan selama masa penempatan TKI di luar negeri sebagaimana dimaksud pada ayat (1) diatur lebih lanjut dengan Peraturan Pemerintah.

Permasalahan yang timbul dari pasal tersebut adalah bahwa dalam Peraturan Pemerintah diatur bahwa Pemerintah Daerah berkewajiban untuk menyelenggarakan dana yang dibutuhkan terhadap kasus TKI yang ditangani oleh Pemerintah Pusat, dengan asumsi bahwa daerah mendapatkan keuntungan dari remintance. Sedangkan Pemerintah Daerah merasa tidak memiliki kewajiban karena perihal pengurusan izin PJTKI menjadi kewenangan pusat, pada hal pada proses ini pusat memperoleh banyak uang. Tarik ulur ini tentu merugikan buruh migran yang bermasalah, karenaya banyak kasus buruh migran yang terjadi justru ditanagani oleh pihak Lembaga Swadaya Masyarakat (LSM)/Ngo.

Selain pihak Pemerintah yang berkewajiban untuk memberikan perlindungan pada buruh migran, maka pihak PJTKI tentunya juga memiliki kewajiban yang sama. Karena secara ekonomis PJTKI jelas diuntungkan dengan proses penempatan TKI ke luar negeri. Hal ini ditegaskan pada Pasal 82 UU No. 39 Tahun 2004 yang berbunyi : Pelaksanaan penempatan TKI swasta bertanggung jawab untuk memberikan perlindungan kepada calon TKI/tKI sesuai dengan perjanjian penempatan.

Secara keseluruhan di dalam UU No. 39 Tahun 2004 perihal perlindungan TKI hanya diatur dalam 8 pasal (Pasal 77- Pasal 84) dari total 109 pasal, karena hampir secara keseluruhan pasal lebih banyak mengatur mengenai substansi dan kebijakan teknis dari penempatan. Karenanya walaupun sudah ada UU ini, namun masih banyak celah hukum dan upaya perlindungan hukumnya belum dapat dilaksanakan secara maksimal oleh Pemerintah.

Dari konsep perlindungan selama ini yang diberikan oleh Pemerintah maupun pihak PJTKI tersebut dapat dilihat bahwa dititik beratkan pada pemberian asuransi 
saja. Dalam Peraturan-peraturan yang ada selama ini Pemerintah tidak pernah mengindentifikasikan perlindungan macam apa yang diberikan pada buruh migran. Kalaupun ada ternyata hal tersebut hanya bersifat formil belaka.

Ini dapat kita lihat dari banyaknya kasus yang terjadi pada buruh migran kita selama ini (yang terjadi di negara tempat bekerja), ternyata baru diketahui setelah mereka pulang kembali ke Indonesia. Dan itupun biasanya lebih awal ditangani oleh pihak LSM pendamping, barulah setelah terekspos dan mendapat tekanan dari berbagai pihak Pemerintah akan melakukan tindakan.

Ini dapat kita lihat dalam beberapa kasus yang menimpa buruh migran, 1994 sepasang suami istri dihukum gantung karena membunuh majikannya, 1997 Sulika telah dieksekusi dengan tuduhan membunuh seseorang, dan ditahun yang sama Nasiroh yang bekerja di Arah Saudi mengalami nasib yang sama didakwa membunuh majikannya. Saat pemerintah menangani kasus Nasiroh ini sudah dalam proses peradilan, artinya Pemerintah baru mengetahui dan menangani kasus buruh migran ketika hal itu sudah terekspos.

Kasus-kasus yang timbul pada buruh migran utamanya kasus yang termasuk tindakan perdagangan perempuan secara nyata terjadi, namun tidak dapat terselesaikan atau ditangani pihak yang berwenang karena tidak adanya pihak yang melindungi keberadaan buruh migran. Padahal jika kita mengacu pada Pasal 82 UU No. 39 Tahun 2004 tentang Kewajiban Pihak PJTKI, yang memberikan perlindungan kepada TKI mulai dari pra pemberangkatan sampai purna pemberangkatan.

Sementara itu keberadaan Perwakilan RI ditempat kerja buruh migran yang dianggap juga dapat memberikan perlindungan pada buruh migran ternyata Perwakilan RI disini hanya berfungsi secara formil saja yaitu mendaftar kedatangan dan kepulangan burauh migran. Jika ada buruh migran yang datang minta pertolongan, mereka akan merekomendasikan kepada pihak mitra usaha dari PJTKI. Bahkan kasus yang terjadi di Kedutaan Besar Indonesia di Arab Saudi berfungsi sebagai tempat penampungan bagi buruh migran yang bermasalah tanpa ada kejelasan kapan kasusunya akan terselesaikan atau siapa yang akan memulangkan mereka. Bahkan adanya tanggapan dari pejabat Deplu bagian Pemburuhan, bahwa pihak Deplu ataupun Perwakilan RI tidak memiliki tugas secara khusus untuk melakukan perlindungan atau penyelesaian kasus yang timbul pada buruh migran pada khususnya, karena tugas mereka disini memberi perlindungan pada warga negara RI secara umum. Untuk permasalahan buruh migran secara khusus ditangani 
oleh bagian perburuhan, inipun hanya bersifat sebagai mediator saja. Sedangkan kewajiban penyelesaian masalah perburuhan tetap berada pada tenaga pihak mitra usaha PJTKI.

Terkait dengan kasus yang dialami oleh buruh migran yang berasal dai Bangkalan dan sampang yang teridentifikasi sebagai tindak perdagangan perempuan, maka berdasarka UU No. 21 Tahun 2007 tentang Pemberantasan Tindak Pidana Perdagangan Orang. Dalam hal ini Pemerintah daerah terkait upaya pencegahan dan penanganan mempunyai kewajiban untuk bersaman-sama melakukannya Ini dapat kita lihat dalam Pasal 57 yang berbunyi : 1) Pemerintah, Pemerintah daerah, masyarakat dan keluarga wajib mencegah terjadinya tindak pidana perdagangan orang 2) Pemerintah dan Pemerintah Daerah wajib membuat kebijakan, program, kegiatan dan mengalokasikan anggaran untuk melaksanakan pencgahan dan penanganan masalah perdagangan orang.

Usaha atau tindakan kongkrit yang dapat dilakukan oleh pemerintah daerah untuk mencegah dan menangani, maka Pasal 58 ayat (2) mengamanatkan : Untuk mengefektifkan dan menjamin pelaksanaan langkah-langkah sebagaimana dimaksud pada ayat (1) pemerintah membentuk gugus tugas yang beranggotakan wakil-wakil dari pemerintah, penegak hukum, organisasi masyarakat, lembaga swadaya masyarakat, organisasi profesi, peneliti dan atau akademisi.

Terkait kebijakan daerah memang dibeberapa daearh di Jawa Timur yang merupakan kantong pengirim buruh migran telah merespon dengan telah membuat Perda yang berupaya untuk memberikan perlindungan pada TKI dan saat ini tengah berupaya untuk membuat Perda terkait perdagangan orang. Sementara untuk kabupaten Bangkalan dan sampangsamapai saat ini belum ada kebijakan, program, kegiatan maupun pengalokasian anggaranuntuk penghentian perdangan orang.

Perihal gugus tugas anti trafficking saat ini di Provinsi sudah ada, yang mana keberadaannya adalah dibeberapa tempat yang merupakan pintu untuk transit, seperti di bandara Juanda dan elabuhan perak. Untuk Bangkalan yang merupakan pintu masuk dan keluarnya dari Madura maka sebaiknya Pemerintah daerah mempunyai gugus tugas daerah yang dapat ditempatkan di Pelabuhan Kamal. Hal ini untuk mencegah pihak-pihak Trafficker saat akan keluar membawa korban. 


\section{Penutup}

Dalam proses pengiriman buruh migran di Bangkalan dan Sampang terdapat berbagai kasus yang timbul, terdapat unsur-unsur perdagangan perempuan yang berupa : a) tindakan melintasi batas, yang merupakan keseluruhan proses pengiriman buruh migran yang dilakukan dengan melakukan pengiriman dari Bangkalan dan Sampang, melintasi perbatasan wilayah Indonesia menuju negara lain, b) adanya tindakan kekerasan atau ancaman kekerasan, tindakan yang terjadi selama di lokasi penampungan, c) adanya penipuan, berupa pemberian janji untuk diberangkatkan bekerja ke luar negeri (telah membayar sejumlah uang) tapi tidak terlaksana, d) lilitan hutang, buruh migran berangkat ke luar negeri dengan tanggungan hutang yang nantinya dibayar dengan uang upahnya, e) kekerasan dengan penyalahgunaan kekuasaan, tindakan majikan untuk menyimpan dokumen dan sebagai pihak yang berkuasa, f) kerja paksa atau kondisi seperti perbudakan, yang dialami buruh migran di tempat kerja.

Keberadaan peraturan tentang buruh migran selama ini sebagian besar hanya mengatur tentang proses penempatan buruh migran. Walaupun ada beberapa pasal yang mengatur mengenai Perlindungan bagi buruh migran, namun pasal-pasal tersebut belum dapat dilaksanakan secara maksimal.

Perlindungan hukum yang sesuai bagi buruh migran guna mencegah terjadinya perdagangan perempuan bagi buruh migran adalah : a) pembuatan bilateral agreement antara negara Indonesia dengan negara pengguna jasa buruh migran, b) pembentukan women desk yang menangani permasalahan buruh migran, c) memperluas fungsi LSM pendamping.

\section{Daftar Pustaka}

Fakih, Mansour, Gender dan Transformasi Sosial, Jakarta, 1998.

Haris, Abdul, Gelombang Migrasi dan Jaringan Perdagangan Manusia, Pustaka Pelajar, Yogyakarta, 2005

LBH Apik dan Pusat Studi Gender FH Unibraw, Naskah Akademik Peraturan Perundangundangan tentang KDRT, Malang, 2000.

Mauna, B., Hukum Internasional Pengertian Peranana Fungsi dalam Era Dinamika Global, Alumni, Bandung, 2000. 
Mashud, Mustain, Perspektif Fenomenologi tentang Trafficking TKW, Jurnal MKP Unair, TahunXXI No.2 April-Juni 2008.

Miko, F. T., Traficking in Women and Children, The US and Internasional Respons, Congressional Research service Report, 2000.

Muchsin, Tindak Pidana Perdagangan Orang, Jurnal Varia Peradilan No 272 Juli 2008.

Marmo Sudjono, Saukarto, Penegakan Hukum di Negara Pancasila, Garuda Metropolis Press, Jakarta, 1989.

M. Hadjon, Phillipus, Perlindungan Hukum Bagi Rakyat di Indonesia, Surabaya, 1987.

Prins, Darwin, Hukum Ketenagakerjaan Indonesia, Citra Aditya Bhakti, Jakarta, 2000.

Tagaroa, R, Laporan tahunan Solidaritas Perempuan, Jakarta, 2000.

Rahayu, Devi, Trafficking Buruh Migran, Qisthos Press, Surabaya, 2008.

Penguatan Hak-hak Buruh Migran Melalui Pelibatan CBO sebagai Upaya Pencegahan Perdagangan Perempuan di Madura, Jurnal MKP Unair, Tahun XXII No. 2 April-Juni 2009.

Solidaritas Perempuan, Dalam Praktek Panduan Melawan Perdagangan Perempuan dan Anak, Jakarta, 2000.

Soesilo, KUHP serta Komentar-komentarnya, Politea, Bandung, 1996.

Sukamdi, et. al., Labour Migration in Indonesia, Population Studies Center, Gadjah Mada University, Yogyakarta, 2000

Stunberg, Nina, "What is trafficking in women and childrenwhat can be done", November, 1999, www.IOM.int, diakses pada 7 Juli 2010

Setiawan, Bony, Stop WTO, INFID, Jakarta, 2000.

Soekanto, Soerjono, Pengantar Penelitian Hukum, Universitas Indonesia, Jakarta, 1986.

Syafa'at, Rachmat, Dagang Manusia : kajian Trafficking terhadap Perempuan dan Anak di Jawa Timur, Lappera Pustaka Utama, Yogyakarta, 2003.

Syafa'at, Rachmat, et. al., Buruh Perempuan : Perlindungan Hukum dan Hak Asasi Manusia, IKIP Malang, 1998. 